\title{
First record of Myzus (Nectarosiphon) persicae (Sulzer, 1776) (Hemiptera: Aphididae) occuring on Valeriana fauriei (Caprifoliaceae)
}

\author{
Первая находка Myzus (Nectarosipbon) persicae (Sulzer, 1776) \\ (Hemiptera: Aphididae) на Valeriana fauriei (Caprifoliaceae)
}

\author{
Daisuke Sasaki \\ Аайсуке Сасаки
}

Kamikawa Agricultural Experiment Station, Hokkaido Research Organization, Minami 1-5, Pippu, Kamikawa, Hokkaido 078-0397, Japan. E-mail: sasaki-daisuke@hro.or.jp

KEY WORDS: green peach aphid, polyphagous pest, new host plant, life cycle, anholocyclic, Japan, Hokkaido.

КЛЮЧЕВЫЕ СЛОВА: зелёная персиковая тля, многоядный вредитель, новое кормовое растение, жизненный цикл, анголоциклический, Япония, Хоккайдо.

ABSTRACT. Valeriana fauriei Briq. is a caprifoliaceous perennial herb cultivated in Japan as a medicinal crop. In 2020, the occurrence of Myzus (Nectarosiphon) persicae (Sulzer, 1776) was found on $V$. fauriei in greenhouses in northern Hokkaido, northern Japan. This is the first report of $M$. persicae occurring on $V$. fauriei in the world. Laboratory experiments revealed that the aphid populations collected from $V$. fauriei were polyphagous and anholocyclic.

РЕЗЮМЕ. Валериана итальянская (Valeriana fauriei Briq.) - многолетнее травянистое растение семейства Жимолостных, возделываемое в Японии как лекарственная культура. В 2020 г. в теплицах на севере Хоккайдо (север Японии) на ней была впервые обнаружена зелёная персиковая тля - Myzus (Nectarosiphon) persicae (Sulzer, 1776). Лабораторные эксперименты показали, что популяции тлей, собранные на $V$. fauriei, были многоядными и анголоциклическими.

\section{Introduction}

Valeriana fauriei Briq. (Japanese common name: Kanoko-sô) is a caprifoliaceous perennial herb distributed in the Russian Far East (Amur Oblast, Khabarovsk Krai, Primorsky Krai, and Sakhalin Oblast: Kuril and Sakhalin Islands), Northeast China (Manchuria), North and South Korea, Japan, and Taiwan [POWO, 2021]. In Japan, this plant is cultivated as a medicinal crop, and its roots and rhizomes are used for "Kissô-kon", a crude drug with sedative effects [Ishida, 2018]. Hokkaido is the largest production area for this crop in Japan.

Uehara-Ichiki [2020] report six plant viruses infecting $V$.fauriei, namely broad bean wilt virus 2 (BBWV-2), cucumber mosaic virus (CMV), gaillardia latent virus (GaILV), ligustrum necrotic ringspot virus (LNRSV), asparagus virus 2 (AV-2), and tomato spotted wilt orthotospovirus (TSWV). BBWV-2 and CMV are transmitted by aphids [Kondo et al., 2005; Koch et al., 2020]. Although the vectors of GaILV and LNRSV are unknown, carlavirus to which the two species belong is commonly transmitted by aphids or whiteflies [Koch et al., 2020]. Therefore, research on aphids occurring on $V$. fauriei is important for the control of viral diseases of this plant.

To date, only four aphid species belonging to the genus Aphis have been recorded on $V$. fauriei, namely A. fabae Scopoli, 1763, A. patriniae Takahashi 1966, A. patvaliphaga Pashtshenko, 1994, and A. spiraecola Patch, 1914 [Blackman, Eastop, 2008, 2021; Higuchi, Miyazaki, 1969; Holman, 2009]. Whereas, V. officinalis L., which is a related species distributed in Europe, is known as a host plant for following 17 aphid species belonging to five genera: A. fabae, A. gossypii Glover, 1877, A patriniae, A spiraecola, A spiraephaga Müller, 1961, A. solanella Theobald, 1914, A. valerianae Cowen, 1895, Dysaphis brancoi (Börner, 1950) [including ssp. rogersoni (Stroyan, 1955)], D. leefmansi (Hille Ris Lambers, 1954) [including ssp. krumbholzi Müller, 1961 and ssp. valentinae Shaposhnikov, 1974], Macrosiphum centranthi Theobald, 1915, Ma. euphorbiae (Thomas, 1878), Ma. rosae (Linnaeus, 1758), Ma. stellariae Theobald, 1913, Ma. valerianae (Clarke, 1903), Myzus ornatus Laing, 1932, M. persicae (Sulzer, 1776), and Sitobion avenae (Fabricius, 1775) [Blackman, Eastop, 2008, 2021; Holman, 2009]. Therefore, V. fauriei may be a host plant of multiple aphid species.

In 2020, the author found a red or green aphid species occurring on $V$. fauriei plants cultivated in greenhouses in Hokkaido Prefecture, northern Japan.

How to cite this article: Sasaki D. 2021. First record of Myzus (Nectarosiphon) persicae (Sulzer, 1776) (Hemiptera: Aphididae) occuring on Valeriana fauriei (Caprifoliaceae) // Russian Entomol. J. Vol.30. No.3. P.247-251. doi: 10.15298/rusentj.30.3.01 
The aphid did not belong to any species previously recorded on this plant. Here, the aphid species was identified. Moreover, the host range and life cycle of the aphid species occurring on $V$. faurie $i$ were examined.

\section{Materials and methods}

\section{Field survey}

Surveys were conducted on nursery $V$. fauriei plants (Fig. 1) cultivated in a greenhouse in Nayoro in April 2020 and on potted $V$. fauriei plants cultivated in a greenhouse in Pippu in October, November, and December 2020. Both study regions located in northern Hokkaido, northern Japan. Aphids were collected in plastic bags with plants and transported to the laborato- ry. The aphid samples were preserved in $70 \%$ ethanol for identification. Parts of the samples collected from Nayoro in April and from Pippu in October were used in rearing experiments.

\section{Identification}

Adult aphids were mounted on slides in Canada balsam following the method described by Martin [1983] and identified based on morphological features following the identification keys described by Miyazaki [1971] and Choi et al. [2019]. The following materials were examined: 10 adult apterous viviparous females (specimen numbers in the author's collection: \#26095-27004): JAPAN, Hokkaido, Nayoro City, Fûren-chô, Midorimachi, on Valeriana fauriei, 7.iv.2020, leg. Daisuke Sasaki; 13 adult apterous viviparous females (\#37098-

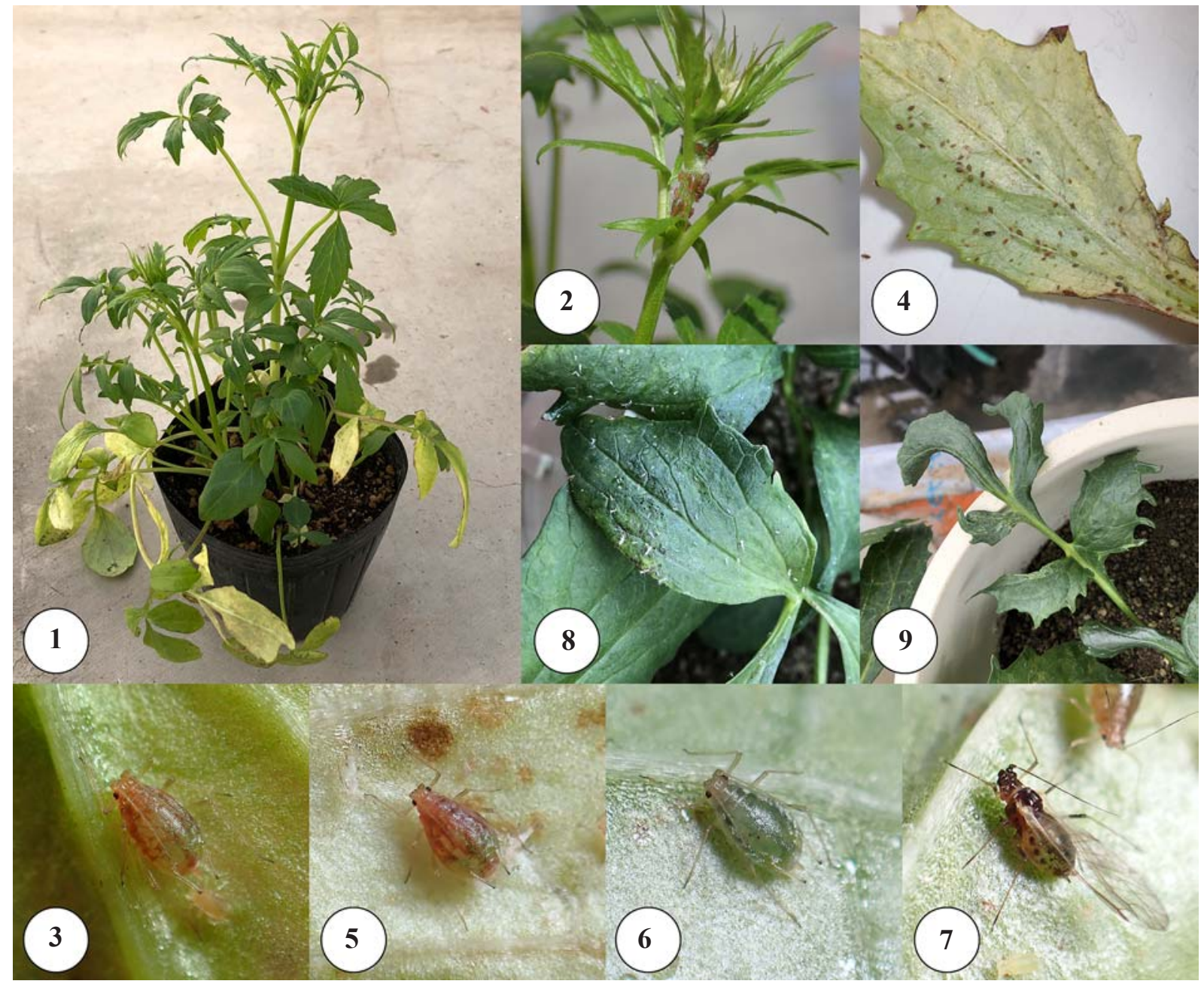

Figs 1-9. Valeriana fauriei plant, Myzus persicae occurring on the plant, and plant damage caused by the aphid: 1 — nursery plant of $V$. fauriei; 2 - colony infesting the plant part near the growing point; 3 - adult apterous viviparous female; 4 - colony infesting the underside of a lower leaf; 5-6 - adult apterous viviparous females; 7 - alate viviparous female; 8 - smearing of the upper side of a lower leaf with honeydew and exuviae produced by the aphids; 9 - withered the leaves of $V$. fauriei; 1-3 - Nayoro (April 2020); 4-7 - Pippu (December 2020); 8-9 - Pippu (November 2020).

Рис. 1-9. Valeriana fauriei, Myzus persicae и повреждения, вызванные тлёй: 1 - саженцы $V$. fauriei; 2 - колония, поражающая часть растения рядом с точкой роста; 3 - взрослая бескрылая живородящая самка; $4-$ колония, поражающая нижнюю часть нижнего листа; 5-6 - взрослые бескрылые живородящие самки; 7 - крылатая живородящая самка; 8 - верхняя сторона нижнего листа, загрязнённая медвяной росой и экзувия тлей; 9 - увядшие листья $V$. fauriei; $1-3$ - Наёро (апрель 2020 г.); 4-7 - Пиппу (декабрь 2020 г.); $8-9$ - Пиппу (ноябрь 2020 г.). 
38010 ) and six adult alate viviparous females (\#3801138016): JAPAN, Hokkaido, Kamikawa-gun, Pippu-chô, Minami 1 sen, on $V$. fauriei, 14.x.2020, leg. Daisuke Sasaki; five adult apterous viviparous females (\#49094 49098) and five adult alate viviparous females (\#4909950003): same date as above except 2.xi.2020; five adult apterous viviparous females (\#50012-50016) and five adult alate viviparous females (\#50017-50021): same date as above except 16.xii.2020.

\section{Host range}

Individual red adult apterous viviparous female collected from each of the two localities (Nayoro and Pippu) were released on potted plants of buckwheat, Fagopyrum esculentum Moench. The two populations (Nayoro and Pippu) derived from each single female were reared at $20{ }^{\circ} \mathrm{C}$ under a 16L:8D photoperiod and used in host range and life cycle experiments. Potted plants of the following six species were examined: $V$. fauriei (Caprifoliaceae), potato (Solanum tuberosum L., Solanaceae; 'Kita-akari'), buckwheat ( $F$. esculentum, Polygonaceae; 'Kita-wasesoba'), broad bean (Vicia faba L., Fabaceae), chard (Beta vulgaris L. var. cicla L., Amaranthaceae; 'Ideal'), and lettuce (Lactuca sativa L., Asteraceae; 'Cisco'). They were infested with adult apterous viviparous females (five adults per a potted plant) and then maintained at 20 ${ }^{\circ} \mathrm{C}$ under a 16L:8D photoperiod. The adults were removed from the plants $24 \mathrm{~h}$ after infestation, and their offspring were observed until they developed into adults. Five replicates were tested for each aphid population and plant species.

\section{Life cycle}

From each of the two populations (Nayoro and Pippu), single red adult apterous viviparous females were transferred to new potted buckwheat plants and reared over four generations at low temperature $\left(15^{\circ} \mathrm{C}\right)$ under a short photoperiod (10L:14D). The generation of the single adult was defined as the first generation. The host plants were replaced with new plants for each generation. Five replicates were tested for each aphid population. Morphs of newborn adults in each generation were morphologically discriminated using a stereo microscope. To determine whether the alate viviparous females that appeared in the third generation in the population from Pippu were gynoparae or alienicolae, the offspring-birth of the alatae and the developments of progeny were observed on new buckwheat plants under the same temperature and photoperiod as above. Offspring-birth of the alatae appeared in the fourth generation in the population was also observed.

\section{Results}

\section{Field survey}

In Nayoro, red aphids colonized the stems and leaves near the growing point (Fig. 2). The colony was small and comprised adult apterous viviparous females (Fig. 3 ) and their nymphs. No apparent plant damage was observed. In Pippu, red or green aphids densely colonized the undersides of lower leaves (Fig. 4) and plant parts near the growing point. The colonies comprised adult apterous and alate viviparous females (Figs 5-7) and their nymphs. In Pippu, the aphids caused smearing of the upper sides of lower leaves with honeydew and exuviae produced by the aphids (Fig. 8) and withering of plant parts near the growing point (Fig. 9). Ant attendance was not observed at either site or any time point.

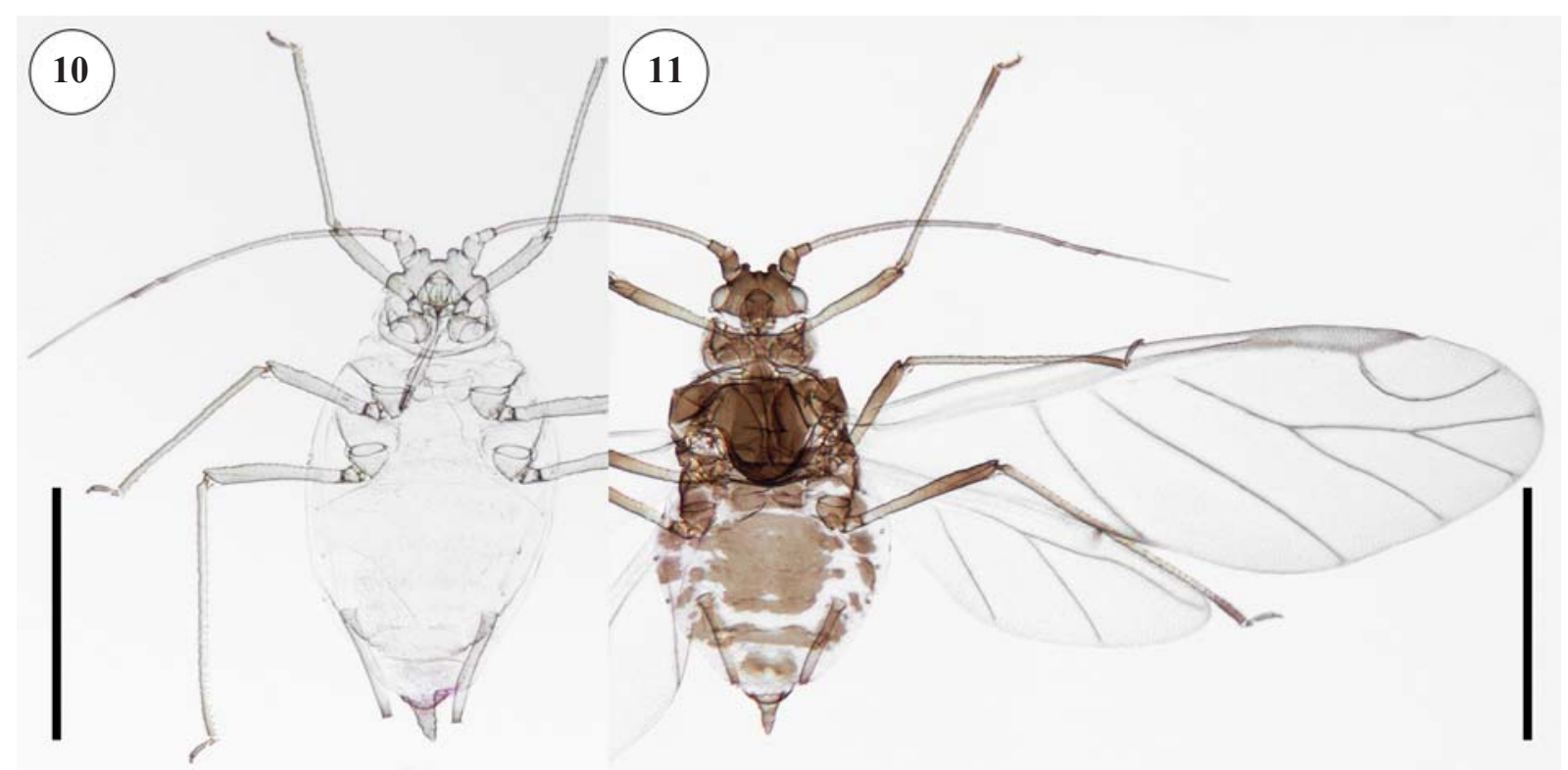

Figs 10-11. Myzus persicae collected from Valeriana fauriei: 10 — adult apterous viviparous female (specimen number: 37098 ); 11 alate viviparous female (specimen number: 38011). Scale bars: $1 \mathrm{~mm}$.

Рис. 10-11. Myzus persicae собранная с Valeriana fauriei: 10 - взрослая бескрылая живородящая самка (номер экземпляра: 37098); 11 - крылатая живородящая самка (номер экземпляра: 38011). Масштабные линейки: 1 мм. 


\section{Identification}

All specimens (Figs 10-11) collected from $V$.fauriei were identified as Myzus (Nectarosiphon) persicae (Sulzer, 1776), commonly known as the green peach aphid or peach-potato aphid, based on the morphological features of adult apterous viviparous females (Fig. 10).

\section{Host range}

The offspring of populations from Nayoro and Pippu developed into adult apterous viviparous females in all replicates of all host plant species.

\section{Life cycle}

Morphs in each of the four generations are shown in Fig. 12. In the population from Nayoro, all adults were apterous viviparous females in all replicates over the four generations. In the population from Pippu, adults were mainly apterous viviparous females in all replicates over the four generations. Five alate viviparous females appeared in one-fifth of the replicates in the third generation. The alatae in the third generation settled and produced offspring on buckwheat. The offspring developed into adult apterous viviparous females on the same plant. One to three alate viviparous females also appeared in all replicates in the fourth generation. They settled and produced offspring on buckwheat. Males were not observed in this experiment.

\section{Discussion}

The present study recorded the occurrence of $M$. persicae on $V$. fauriei. This is the first report of $M$. persicae occurring on $V$. fauriei in the world. In the field survey in Pippu, some damage to $V$. fauriei caused by $M$. persicae was observed. Therefore, $M$. persicae can be regarded as a pest of $V$. fauriei. In addition, $M$. persicae is a highly efficient vector of plant viruses and can transmit over 100 virus species [Blackman, Eastop, 2017]. Thus, M. persicae may also be important as a vector of viral diseases of $V$. fauriei. Additional aphid species on $V$. fauriei must be recorded in further studies.

Host range experiment indicated that $M$. persicae populations from Nayoro and Pippu were able to reproduce on six plant species, including $V$. fauriei, belonging to different plant families. This result is consistent with polyphagy which is a typical characteristic of $M$. persicae [Blackman, Eastop, 2017; Van-Emden et al., 1969].

In the life cycle experiment, all adults in the population from Nayoro were apterous viviparous females. In the population from Pippu, most adults were apterous viviparous females, although alate viviparous females also appeared. The alatae could by either gynoparae or alienicolae. In this experiment, all alatae settled and produced offspring on buckwheat. This result indicates that the alatae were alienicolae, not gynoparae, because the gynoparae of $M$. persicae reproduce only on Prunus and some related genera [Van-Emden et al., 1969]. Moreover, males did not appear in either populations. Based on the above results, both $M$. persicae populations were anholocyclic, not holocyclic, androcyclic, or intermediate [Margaritopoulos et al., 2002].

According to Hori [1929]'s statement about holocyclic life cycle of $M$. persicae in Hokkaido, the emigrants appear in early to late June and the immigrants (= gynoparae) appear in mid to late October. However, in the

\section{N. 5/5 rep. P. $4 / 5$ rep. $\quad$ P. $1 / 5$ rep.}

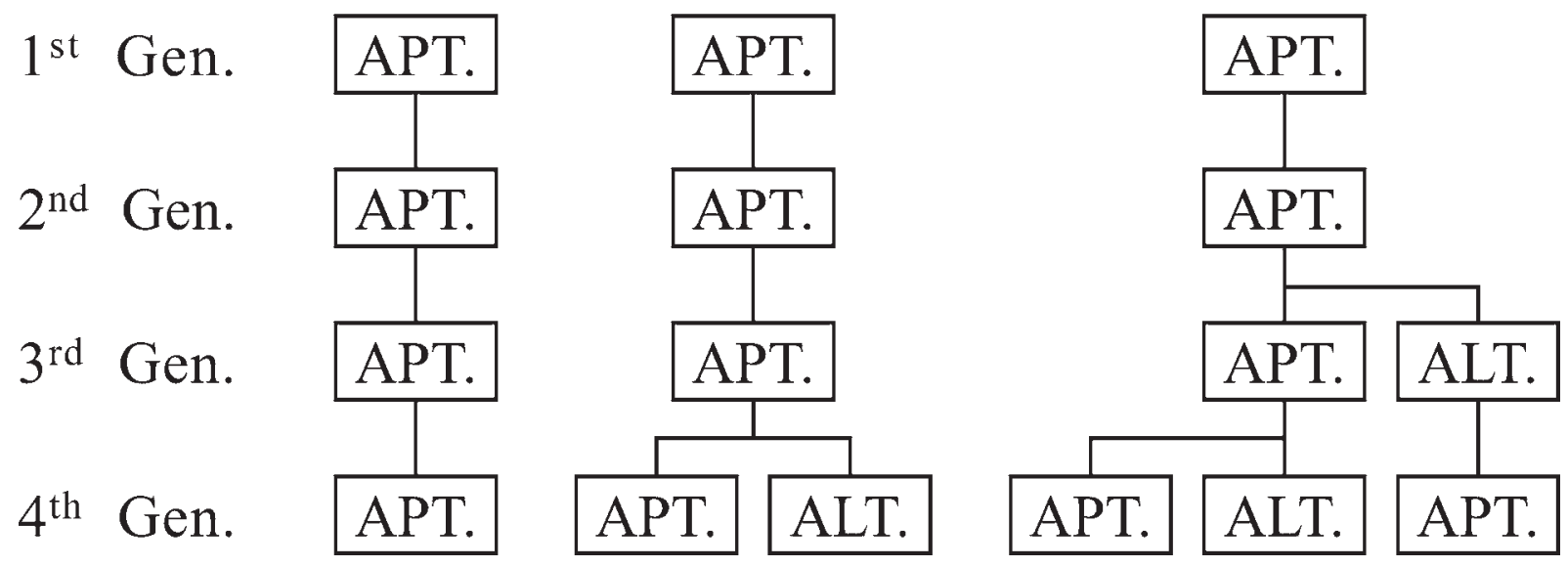

Fig. 12. Morphs of two M. persicae populations reared on buckwheat plants $\left(15^{\circ} \mathrm{C}, 10 \mathrm{~L}: 14 \mathrm{D}\right)$ over four generations $(\mathrm{Gen}-\mathrm{generation}$ of the single adult viviparous female initially transferred on buckwheat at maintained $\left(15^{\circ} \mathrm{C}, 10 \mathrm{~L}: 14 \mathrm{D}\right)$ was defined as the first generation; $N$ - population from Nayoro; $P$ - population from Pippu; rep - replication; $A P T$ - apterous viviparous female; $A L T$ - alate viviparous female).

Рис. 12. Морфы двух популяций M. persicae, выращенных на растениях гречихи $\left(15^{\circ} \mathrm{C}, 10 \mathrm{~L}: 14 \mathrm{D}\right)$, в течение четырёх поколений (Gen - поколение единственной взрослой живородящей самки, первоначально перенесённоq на гречиху (15 $\left.{ }^{\circ} \mathrm{C}, 10 \mathrm{~L}: 14 \mathrm{D}\right)$, было принято как первое поколение; $N$ - популяция из Наёро; $P$ - популяция из Пиппу; rep - размножение; $A P T-$ бескрылая живородящая самка; $A L T$ - крылатая живородящая самка). 
present field survey, the viviparae of $M$. persicae were observed in early April in Nayoro and in mid December in Pippu. This result supports the conclusion of the life cycle experiment that the populations from both Nayoro and Pippu were anholocyclic.

Miyake et al. [2017] report $M$. persicae parthenogenetically overwintering in many greenhouses in eastern Hokkaido and consider them anholocyclic for the following two reasons: (1) colonies in the greenhouses in winter were consisted of only apterous adults and nymphs; (2) males were not observed in October among $M$. persicae alatae occurring on sugar beets cultivated outdoors in the same survey area. The present study experimentally revealed that $M$. persicae populations from Nayoro and Pippu in northern Hokkaido are anholocyclic. This result more certainly indicates that the anholocyclic populations of $M$. persicae are distributed even in Hokkaido, where almost the entire region has a subarctic climate.

Acknowledgements. The author is grateful to Mr. Katsuhiro Furukawa (Kamikawa Agricultural Experiment Station, Hokkaido Research Organization) and Mr. Akihiro Mori (Agricultural Technologies Dissemination Division, Department of Agriculture, Hokkaido Government) for their cooperation for my research.

\section{References}

Blackman R.L., Eastop V.F. 2008. Aphids on the world's herbaceous plants and shrubs, 2 volume set. New York: John Wiley \& Sons. $1460 \mathrm{pp}$.

Blackman R.L., Eastop V.F. 2017. Taxonomic Issues // Van-Emden H.F., Harrington R. (eds.). Aphids as Crop Pests, 2nd Edition. Wallingford: CABI. P.1-36.

Blackman R.L., Eastop V.F. 2021. Aphids on the World's Plants http://www.aphidsonworldsplants.info/ (Accessed on 10 February, 2021)
Choi H., Kim H., Lee W., Lee M., Shin S., Lee S. 2019. Taxonomic review of genus Myzus (Hemiptera: Aphididae) in the Korean peninsula, with descriptions of three new species // Journal of Asia-Pacific Entomology. Vol.22. No.3. P.675-683.

Higuchi H., Miyazaki M. 1969. A tentative catalogue of host plants of Aphidoidea in Japan // Insecta Matsumurana. Supplement. Vol.5. P.1-66.

Holman J. 2009. Host plant catalog of aphids. Dordrecht: Springer. $1140 \mathrm{pp}$.

Hori M. 1929. [Major Aphids on Agricultural and Horticultural Crops in Hokkaido] // Report of the Hokkaido Agricultural Experimental Station. Vol.23. P.1-163 [in Japanese].

Ishida N. 2018. Characteristics of Medicinal Crop Production in Hokkaido, Japan // Geographical Studies. Vol.93. No.1 P.1-7. [in Japanese].

Koch K.G., Jones T.K.L., Badillo-Vargas I.E. 2020. Arthropod vectors of plant viruses // Awasthi L.P. (ed.) Applied Plant Virology. London: Academic Press. P.349-379.

Kondo T., Fuji S.I., Yamashita K., Kang D.K., Chang M.U. 2005. Broad bean wilt virus 2 in yams // Journal of General Plant Pathology. Vol.71. No.6. P.441-443.

Martin J.H. 1983. The identification of common aphid pests of tropical agriculture // Tropical Pest Management. Vol.29. No.4. P.395-411.

Margaritopoulos J.T., Tsitsipis J.A., Goudoudaki S., Blackman R.L. 2002. Life cycle variation of Myzus persicae (Hemiptera: Aphididae) in Greece // Bulletin of Entomological Research. Vol.92. No.4. P.309-319.

Miyake N., Yasuoka S., Ueda S., Takashino K. 2017. Occurrence and Suppression of Beet Western Yellows in Sugar Beet Beta vulgaris: 1, Identification of the Vector Insect in Eastern Hokkaido // Annual report of the Society of Plant Protection of North Japan. Vol.68. P.179-184. [in Japanese].

Miyazaki M. 1971. A revision of the tribe Macrosiphini of Japan (Homoptera: Aphididae, Aphidinae) // Insecta Matsumurana. Vol.34. No.1. P.1-247.

POWO. 2021. Plants of the World Online. Facilitated by the Royal Botanic Gardens, Kew. Published on the Internet: http:// www.plantsoftheworldonline.org/ (Accessed on 24 February 2021).

Uehara-Ichiki T., Ohashi M., Hanada K., Igarashi M., Hishida A. 2020. Identification and pathogenicity of plant viruses infecting Valeriana fauriei in Japan // Journal of General Plant Pathology. Vol.86. No.4. P.310-315.

Van-Emden H.F., Eastop V.F., Hughes R.D., Way M.J. 1969. The ecology of Myzus persicae // Annual Review of Entomology. Vol.14. No.1. P.197-270. 